\title{
Biomimetics: forecasting the future of science, engineering, and medicine
}

\author{
This article was published in the following Dove Press journal: \\ International Journal of Nanomedicine \\ 8 September 2015 \\ Number of times this article has been viewed
}

\author{
Jangsun Hwang' \\ Yoon Jeong ${ }^{1,2}$ \\ Jeong Min Park ${ }^{3}$ \\ Kwan Hong Lee ${ }^{1,2,4}$ \\ Jong Wook Hong ${ }^{1,2}$ \\ Jonghoon Choi ${ }^{1,2}$ \\ 'Department of Bionano Technology, \\ Graduate School, Hanyang University, \\ Seoul, ${ }^{2}$ Department of Bionano \\ Engineering, Hanyang University \\ ERICA, Ansan, Korea; ${ }^{3}$ Department \\ of Biomedical Engineering, Boston \\ University, ${ }^{4}$ OpenView Venture \\ Partners, Boston, MA, USA
}

\begin{abstract}
Biomimetics is the study of nature and natural phenomena to understand the principles of underlying mechanisms, to obtain ideas from nature, and to apply concepts that may benefit science, engineering, and medicine. Examples of biomimetic studies include fluid-drag reduction swimsuits inspired by the structure of shark's skin, velcro fasteners modeled on burrs, shape of airplanes developed from the look of birds, and stable building structures copied from the backbone of turban shells. In this article, we focus on the current research topics in biomimetics and discuss the potential of biomimetics in science, engineering, and medicine. Our report proposes to become a blueprint for accomplishments that can stem from biomimetics in the next 5 years as well as providing insight into their unseen limitations.
\end{abstract}

Keywords: biomimicry, tissue engineering, biomaterials, nature, nanotechnology, nanomedicine

\section{Introduction}

If the history of planet Earth was compressed into 1 year, humans would appear in the last 15 minutes of it. Out of those 15 minutes, most recent industrial progress would occur within 1 minute. ${ }^{1}$ Despite this small proportion, the industrialization that took place in the last century is much greater than that from the start of mankind. Although the rapid rate of industrialization has helped to prolong life and overcome disease, it has also brought pollution and environmental destruction, which affect human survival itself. In this drift toward industrialization, men have made a continuous effort to create more products that can improve our lives. However, the survival of mankind faces the physical dilemma of living on limited resources. Solutions to the lack of resources and survival problems have not always been clear to us, although the answer can always be found within nature. An interesting method to solve these problems may lie in biomimetics, which uses nature as the ultimate model, standard, and advisor. ${ }^{1,2}$ In recent times, mankind has newly opened its eyes to biomimetic technology, and its efforts are being met with success. This review focuses on recognizing specific examples of biomimetics, their current use, and how they will continue to be used in the future.

\section{Biomimetics: past, current, and future Definition and concept of biomimetics \\ Definition of biomimetics}

The term "biomimetics" originates from the Greek words "bios" (life) and "mimesis" (to imitate), yet its definition is not as simple as just those two words. More specifically, biomimetics is a creative form of technology that uses or imitates nature to improve human lives. 


\section{Concept of biomimetics}

Biomimetics is not a recent study or trend, but the idea of looking into nature for inspiration has been in practical use for a long time. It has been called by different names such as "intellectual structure" in Japan and "smart material" in the USA. Biomimetics is centered on the idea that there is no model better than nature for developing something new and has produced excellent results in productivity and function. This idea has also opened doors to realistic gains by eliminating waste and saving in research expenses. ${ }^{2}$

\section{Field of biomimetics}

Humans have heavily impacted nature with industrialization and resource extraction; however, biomimetics can help to avoid this pattern. Biomimetics goes beyond simply using natural properties as the basis for innovation of new products. Such products can be designed to play a part in general industry as well as to provide human convenience in the fields of chemistry, biology, architecture, engineering, medicine, and biomedical engineering (Figure 1). Such a symbiotic relationship plays a critical role in the coexistence of humans with nature, and the extent of its application can be boundless. It is therefore critical to understand these areas and examples for each of them. ${ }^{1,3}$

\section{History of biomimetics and research methods}

\section{The history of biomimetics}

Found easily in everyday life and often used without our knowledge, biomimetics is a broad field with a long history. From knives and axes inspired by the dental structures of

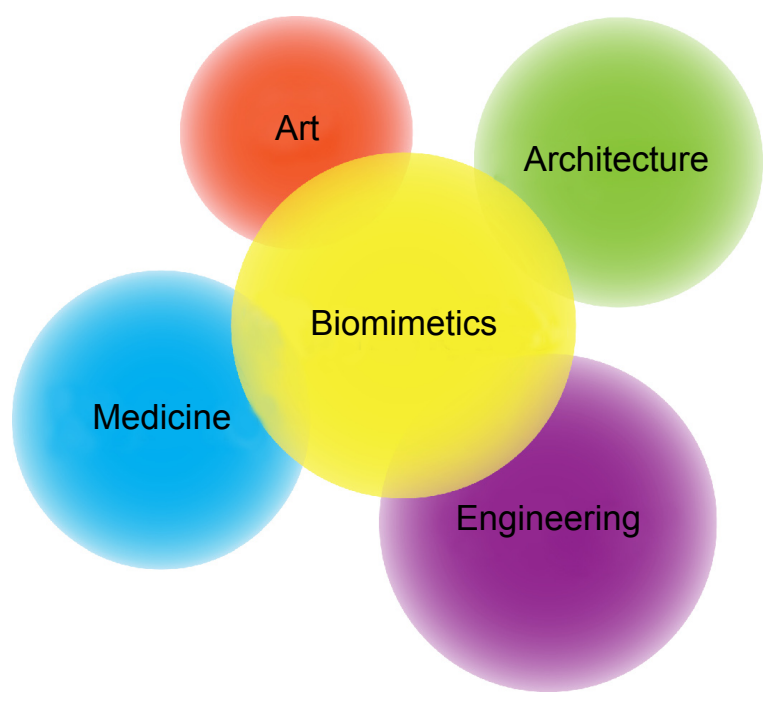

Figure I The area of applications in biomimetics. currently extinct animals to the strongest cutting-edge carbon nanomaterials, bioengineering has always evolved along with human history.

Leonardo da Vinci's (1452-1519) work is a fundamental example of biomimicry. He designed a "flying machine" inspired by a bird. ${ }^{4}$ In the Far East, General Yi Sun-sin built the turtleship, a warship modeled after a turtle, to fight Japanese raiders during invasions. ${ }^{5}$ The Wright brothers (1867-1948) took note of the wings of eagles and made a powered airplane that succeeded in human flight for the first time in 1903. Over the next century, the airplane became faster, more stable, and more aerodynamic. ${ }^{6,7} \mathrm{Schmitt}$ was the first to coin the term biomimetics in 1957, and he announced a turning point for biology and technology. ${ }^{8}$ Jack E Steele of NASA, who coined the word bionics in 1960, was also the first to use the word biomimetics in a paper in 1969, which led to the addition of the term to the dictionary in 1974. In 1997 , Janine M Benyus published her book Biomimicry, which emphasizes that biomimicry is leading the path to a new age of technological development by taking lessons from nature as the groundwork for products, rather than just using it for raw materials (Figure 2). ${ }^{1}$ Janine Benyus and others stepped further to organize a social enterprise called Biomimicry 3.8 to share ideas and concepts of biomimicry and biomimetics as well as to connect interdisciplinary researchers, scientists, artists, engineers, business leaders, and stakeholders.

\section{Research methods for biomimetics}

The basic research method for biomimetics has six steps, which can be used to apply biomimetics to design, product, service, and agriculture. ${ }^{2}$

Like the sticky substance found in geckos' feet, ${ }^{3,9,10}$ the functional possibilities of biologically inspired design should be researched rather than just applying the design as it is used by the organism. Although the discovery or fusion of innovative technology is crucial for increased profits, a simple creative design idea can provide greater convenience for human life.

The function of the organism, the principles under which that function is achieved, and the relationship between these two must be established. Knowledge and application of various materials need to be accumulated through research and database compilation. The relationship between structure and function usually comes from the surface structure, which can be observed by a scanning electron microscopy technique. These fine structures play an important role in the organism and are said to be the first step for biomimetics. The US researchers are using the Biomimicry Taxonomy as a practical database (Figure 2). 


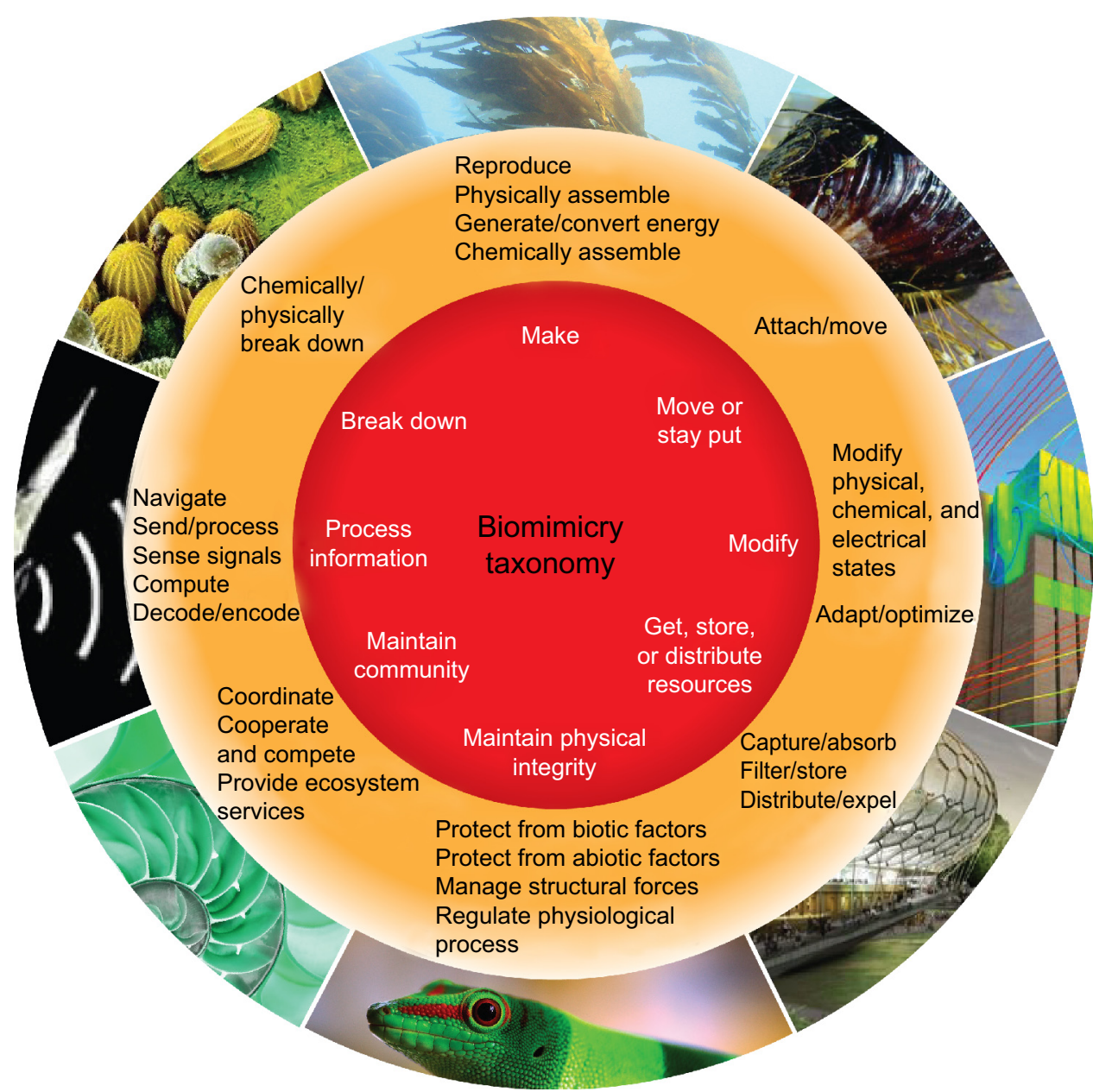

Figure 2 Biomimicry taxonomy categorizing the research interests of biomimetics.

Note: Republished with permission of Springer Science and Business Media, from Biologically Inspired Design: Computational Methods and Tools, Goel AK, McAdams DA, Stone RB, editors, (C Springer-Verlag London 2014; permission conveyed through Copyright Clearance Center, Inc."

The greatest challenge faced by biomimetics is to determine how nano- and microstructures function in their relationship with the organism and the environment, especially if these have not been fully explored yet. ${ }^{2}$ Finding substantial examples through the integration of biology, natural history, and materials science is the next step in biomimetic research.

Identifying various functional and environmental adaptation mechanisms of organisms and their energy-minimizing design is the next research frontier. ${ }^{2}$ A successful example of this is the antireflective coating that was inspired by the $200 \mathrm{~nm}$ structures reflecting visible light rays from a moth's eye. ${ }^{2,12,13}$ The nature of new biomimetic materials lies in discovering hierarchical structures and their corresponding functions to remodel them into something we can utilize.

The combination of newly discovered materials with biomimetics research will be a key to understanding their applications and limitations. ${ }^{2}$ The morphological and functional uses of the new material must first be understood along with the pros and cons of biomimetics, and the results from their combination have to be unraveled. Active research is being performed on these fronts, but making progress in these areas is realistically a difficult pursuit.

The determined biological material's structure and the function become the source of innovation for the development of a new material while possibly providing links to other materials. ${ }^{2}$ The structure and function of already known materials go through tests and assessments that help them morph and evolve into new materials. By combining them with current advancements in medicine, chemistry, and nanotechnology, we may find novel utilities that may benefit human life.

\section{Examples of biomimetics in industry Velcro}

The name Velcro, a common hook-and-loop fastener, comes from the French words for velvet, "velour," and hook, 
"crochet". ${ }^{14}$ In the early 1940s, Swiss engineer George de Mastral noticed the tendency of the fruit of the burr (Xanthium strumarium) to stick to dog's hair and used a microscope to observe the hooks on the fruit which attach to animal hair. He discovered that an elliptical fruit with a length of $1 \mathrm{~cm}$ had densely packed hook-like projections. These latched onto peoples' clothing or animals' hair, allowing seeds to be dispersed widely. Inspired by this burr, de Mastral used nylon to create velcro fasteners. To enhance adhesive abilities, velcro consists of a strip with round loops and a strip with burr-like hooks. For its small surface area, velcro has exceptional adhesive strength and is used extensively as a simple and practical substitute for buttons or hooks in clothing and shoes. ${ }^{14-18}$

\section{Aircraft}

The emergence of airplanes realized the age-long dream of mankind to fly, but it was also a groundbreaking form of transportation. The basic structure of the wings of airplanes consists of a differing sized curved surface on the upper and lower part of the wing that creates hydrodynamic forces explained by the Bernoulli effect. Through this hydrodynamic structure, the velocity of the airstream is faster on the upper part of the wings and slower on the bottom part of the wings. The higher pressure from the bottom of the wings and the speed of the plane enables the 100 ton airplane to fly. This was the principle that led the Wright brothers to succeed in their first flight, but it was also the result of numerous years of biomimetic research on the structure and design of birds' wings and their feathers. Beyond individual birds, a flock of wild geese fly in a $\mathrm{V}$ formation, creating an ascending air current allowing those flying behind to fly with less effort. ${ }^{19,20}$ AIRBUS, a French aviation company, uses these principles to design their planes. Furthermore, birds that fly short and long distances have different feathers and shapes. These insights have been used to design airplanes that have to travel shorter and longer distances in a different manner. ${ }^{21,22}$

\section{Automobiles}

Over the most recent decade, automobile design has not only had an influence on the exterior of cars, but also had an influence on their function. ${ }^{23-25}$ The economizing and energy efficient aspects of biomimetics have been adopted in cars as demonstrated by DaimlerChrysler's prototype bionic concept car (Figure 3).

\section{A}

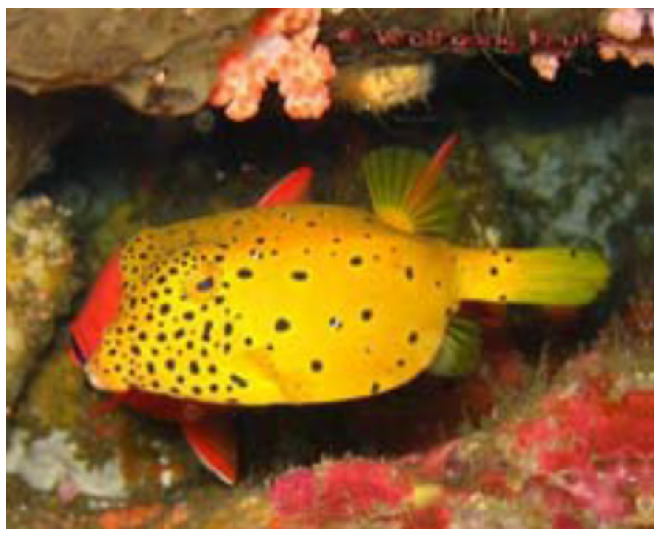

C

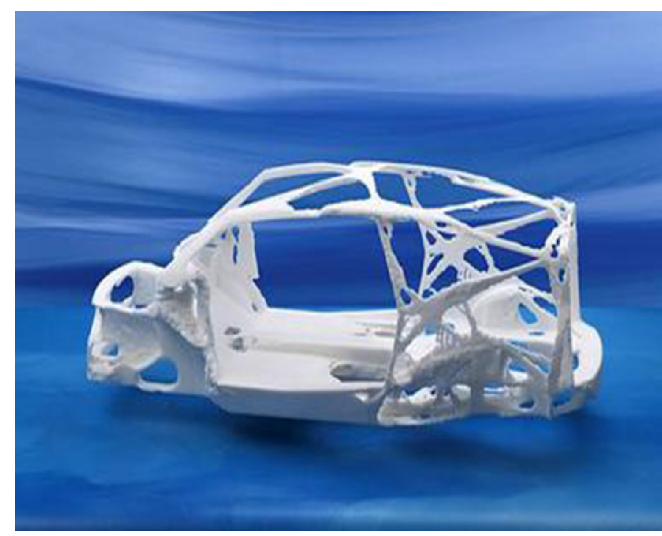

B

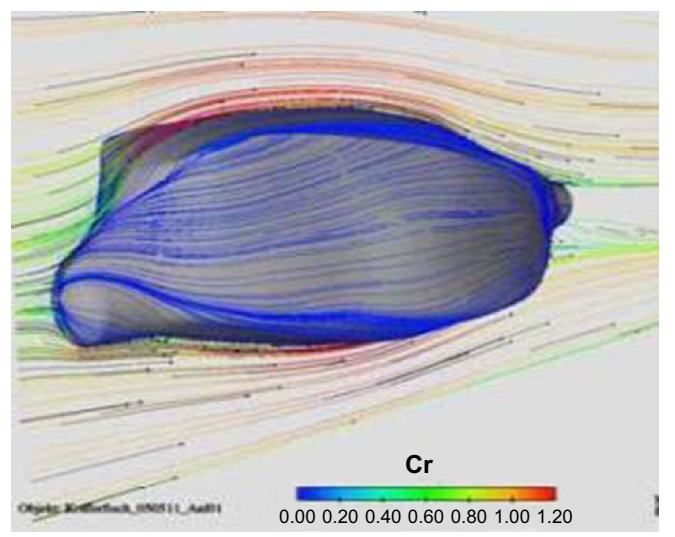

D

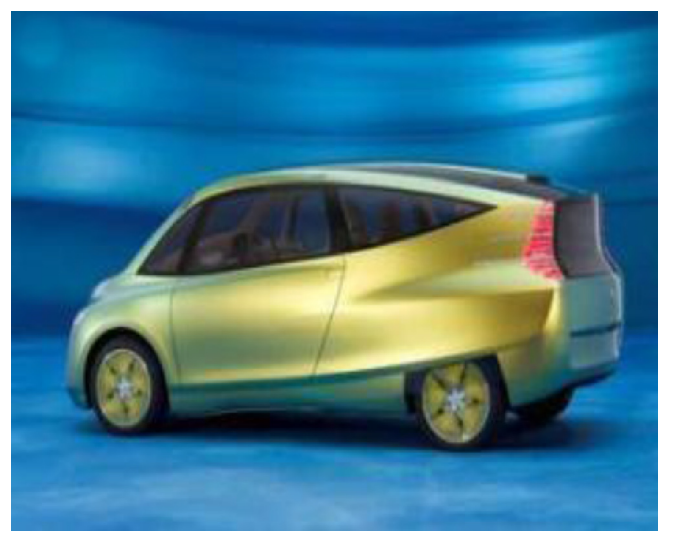

Figure 3 DaimlerChrysler's prototype bionic car (D), inspired by the box fish (A), skeleton structure of blowfish adapted for designing of vehicles (C), and tree growth patterns (B).

Note: Republished with permission of Springer Science and Business Media, from Bannasch RB. Technology Guide. Springer;2009:178-183, (c) Copyright 2009; permission conveyed through Copyright Clearance Center, Inc. ${ }^{28}$ 
The exterior of this car is based on the shape of the boxfish (Figure $3 \mathrm{~A}$ and B), making it stable and aerodynamic. The basic structure of this car consists of a large outward appearance and small wheels, and the design was evaluated through computer simulation to achieve a minimal stress concentration. This car has an average fuel efficiency of $70 \mathrm{mi} / \mathrm{gal}(23 \mathrm{~km} / \mathrm{L})$ and a maximum speed of $190 \mathrm{~km} / \mathrm{h}$, making it more fuel efficient than any existing car (Figure 3C and D). ${ }^{26,27}$

The front of the Japanese bullet train was inspired by a kingfisher's beak, so that the sonic boom when the train exits a tunnel and air resistance can be minimized while acceleration and energy efficiency can be increased. ${ }^{29,30}$ This idea was taken from the observation that a kingfisher dives perpendicular to the surface of the water when hunting, causing minimal splashing. Since it simulated the rounded beak structure of the kingfisher, the Shinkansen also came to be known as the bullet train. Another example is SkinzWraps, a film inspired by the microprojections on shark skin to repel germs (Figure 4). The use of SkinzWraps in automobiles reduced car pollution and increased fuel efficiency by
$18 \%-20 \%$. It has also been applied to swimsuits, bringing better results for athletes. ${ }^{4,31}$

\section{Architecture}

Biomimicry has the longest history of application in architecture. Previous biomimetic technologies are being used to this day and will be developed further. The most notable example of biomimetic architecture is the $6 \mathrm{~m}$-tall termite's nest in the African grasslands. These nests are built from soil, tree bark, sand, and termite saliva, yet they are firmer than concrete. ${ }^{32-34}$

Termites are extremely sensitive to heat, as they live in groups of over 2 million. Even when the external temperature is as high as $40^{\circ} \mathrm{C}$, the nests maintain an internal temperature of $30^{\circ} \mathrm{C}$. Although it seems that termites only developed this system due to their sensitivity to external stimuli, it is more effective at maintaining temperature than any ventilation, heating, and cooling systems made by man. ${ }^{35}$

Mike Pearce from Zimbabwe took note of these characteristics of termites' nests and constructed Eastgate Centre, the world's first all-natural cooling structure, in Zimbabwe's

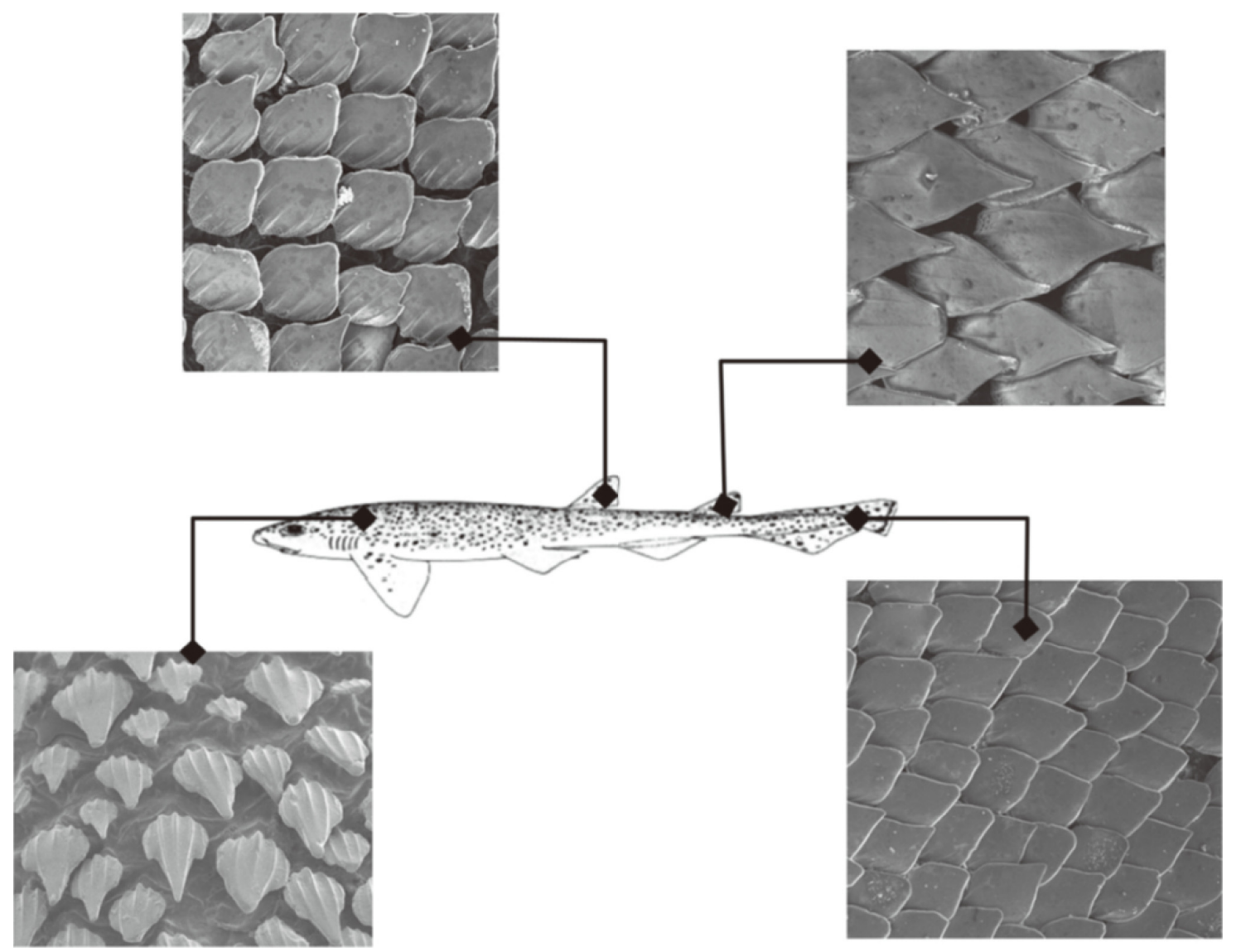

Figure 4 SEM images illustrating the variation in dermal denticle shapes across the body surface of Scyliorhinus canicula.

Note: () IOP Publishing. Reproduced with permission from Sullivan T, Regan F. The characterization, replication and testing of dermal denticles of Scyliorhinus canicula for physical mechanisms of biofouling prevention. Bioinspiration and Biomimetics. 201 I;6(4):04600 I, doi: I0.1088/I748-3 I82/6/4/04600 I. All rights reserved. ${ }^{32}$ Abbreviation: SEM, scanning electron microscopy. 

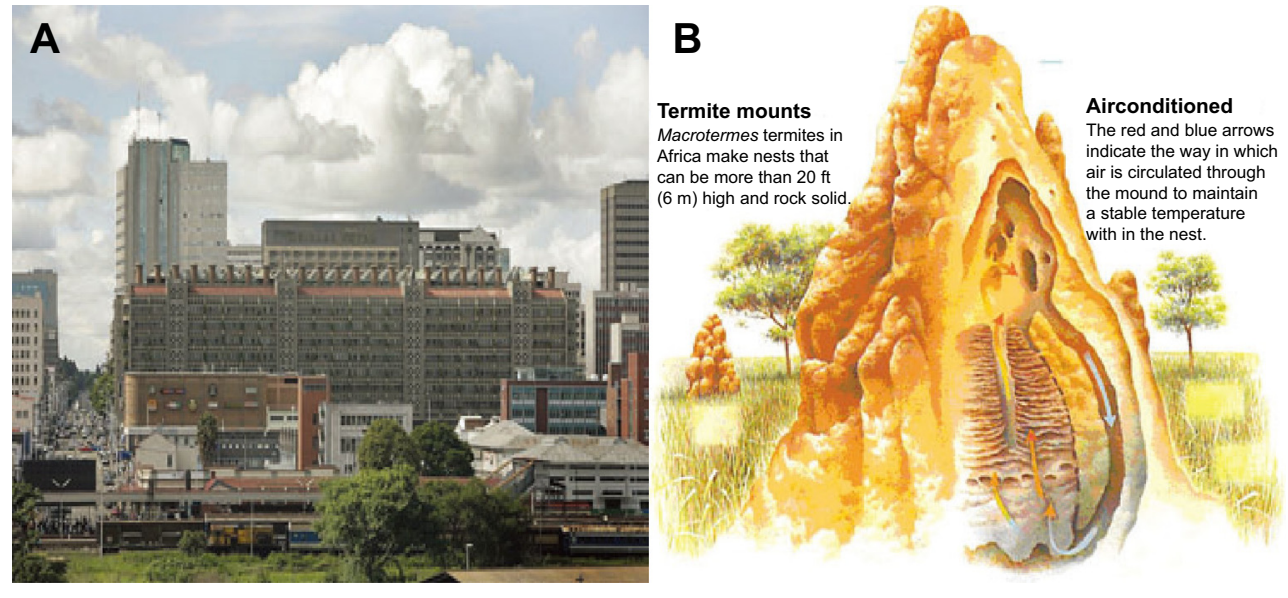

Figure 5 The Eastgate building in Harare, Zimbabwe, adapting the design of nests of termites.

Notes: Constructed building based on the design of termites' nest (A) and internal structure and air flow of termite nest (B). (C) John Wiley and Sons 20I0. Reproduced with permission from John Wiley and Sons, from French JR, Ahmed BM. The challenge of biomimetic design for carbon-neutral buildings using termite engineering. Insect Sci. 2010;17(2): $154-162 .^{37}$

capital, Harare (Figure 5A and B). This building has holes on the roof and the lower floors to allow natural ventilation, similar to what a termite's nest does. Hot air exits through the roof, and the influx of the cold air from the bottom ventilates the building. Hence, the energy consumption rate of this building is $<10 \%$, and an internal temperature of $24^{\circ} \mathrm{C}$ is maintained even when the external temperature is higher than $38^{\circ} \mathrm{C} .^{35-37}$

Furthermore, the Esplanade Theater (Michael Wilford \& Partners, DP Architects) in Singapore has a unique exterior that is reminiscent of the eyes of a fly or the surface of a durian fruit. Over 2,000 aluminum projections cover the exterior glass walls, each providing a shade for each glass wall of the greenhouse-shaped Esplanade Theater. As a result, the theater has a unique exterior while being very practical. ${ }^{38}$

\section{Antireflective coatings}

Areflexia is a phenomenon observed in a moth's eyes, which reflect all wavelengths of light beyond the visible light spectrum to block them. The projections on moths' eyes, spaced at intervals of $200 \mathrm{~nm}$, absorb most visible light rays, as they are shorter than most wavelengths of light. The refraction of the light rays entering the eyes is increased, significantly decreasing reflection. This allows the moth to avoid predators and to see prey in the dark. This technology is being used not only for military purposes but also for solar cell light-emitting diodes. ${ }^{12}$

\section{High-strength carbon nanotubes}

Mussels do not detach easily from rocks even when hit by powerful waves because they have high adhesive strength, which is due to byssi. A byssus pad with a radius of $2 \mathrm{~mm}$ is capable of lifting weights up to $12.5 \mathrm{~kg}$. The adsorptive power of byssi is greater than any adhesive found in nature. The structure of byssi is composed of the crosslinking of collagen fibers and a protein known as Mefp-1, which is more durable than any fiber (Figure 6B). ${ }^{39-41}$

Cultured carbon nanotube (CNT) fibers and cross-linked macromolecule adhesives acting as collagen and Mefp-1 protein, respectively, led to the development of high-strength CNTs. This led to the innovative development of highstrength CNTs with a significant reduction in thickness from $100 \mathrm{~nm}$ to $17.1 \mathrm{~nm}$ while creating three times the strength. The properties of byssi have also led to their use in modern medicine to create new ways of stitching wounds and utilizing them in surgery. ${ }^{42,43}$

\section{Self-healing concrete adhesive supply pipe}

Current research in self-healing concrete focuses on diverse areas of adhesive supply pipes, the inclusion of fibers to provide inherent adhesive properties and to create shape-memory alloys and leavening agents. ${ }^{44}$ More recently, progress is being made on self-healing concrete through nanoconstruction materials ${ }^{45-47}$ (Figure 7). In this case, biomineralization technology is used to provide concrete with self-healing abilities. Sporosarcina pasteurii uses water, calcium ion, and carbon dioxide $\left(\mathrm{CO}_{2}\right)$ in its metabolism and creates calcium carbonate $\left(\mathrm{CaCO}_{3}\right)$ through calcification. This calcium carbonate fills the gap in the concrete. In addition, the cement complex is augmented with fiber that has a higher elastic modulus and aspect ratio to improve the tension and metamorphosis. ${ }^{48}$ 


\section{Robots}

Biomimetic technology is currently being used in various fields such as design, agriculture, chemistry, medicine, and material science. It has also been incorporated in robotics research, giving rise to a novel field of biomimetic robotics. ${ }^{49,50}$ The motor mechanisms of animals and insects are being imitated, which has a significant influence on the motility of the machine, previously limited by wheels. In 1998, Dr Robert Full researched the mechanisms of cockroach legs to make a RHex (Figure 8) with robotic legs and feet that overcomes the limitation of wheels. ${ }^{51}$ At Carnegie Mellon University, Dr Howie Choset is developing robotic arms that apply the mechanisms of bones and joints of a snake (Figure 9) and an elephant's trunk. ${ }^{52}$ Moreover, Dr Robert Full and Dr Fon Fearing developed an iRobot sensitive to pressure and therefore capable of effective dry adhesion, inspired by the microhairs on the soles of a gecko ${ }^{3,9}$

\section{Current market size of biomimetics}

In Europe, Japan, and the USA, biomimetics is being recognized as the technology of the future and there is increasing interest and funding. In particular, global companies such as Ford, General Electric, Herman Miller, HP, IBM, and Nike are collaborating with scientists and designing laboratories to explore novel technologies.

Between 2005 and 2008, the market size for products and construction projects that applied biomimetics was estimated to be above $\$ 1.5$ billion. By 2025 , industry analysts project that products and services in biomimicry will increase to

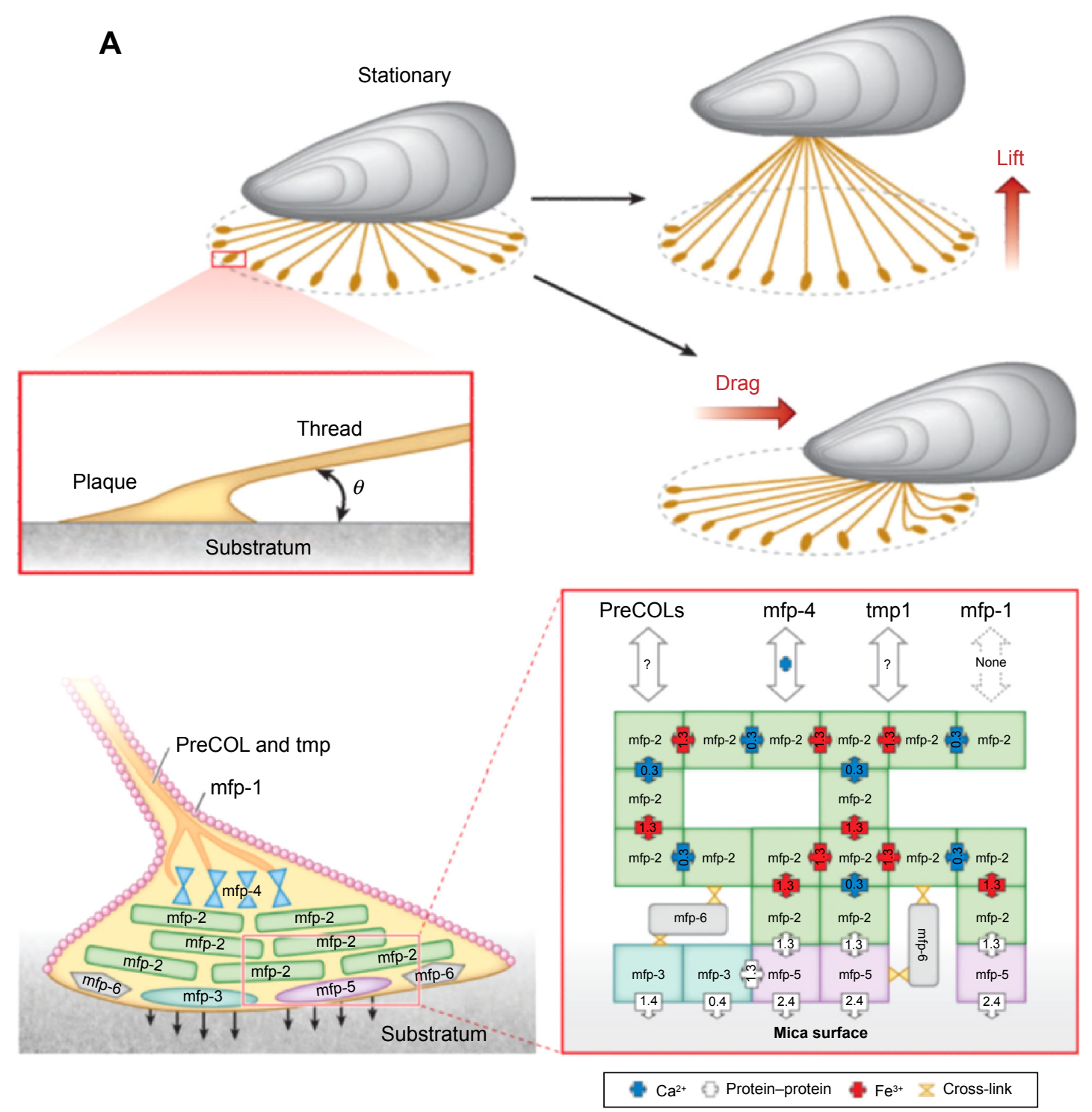

Figure 6 (Continued) 


\section{B $\mathrm{H}_{3} \mathrm{~N}-$ ADYYGPNYGP PRRYGGGNYNRYNRYGRRYGGYKGWNNGWNRGRRGKYW-COOH}<smiles>CC(=O)C(Cc1ccc(O)c(O)c1)NC(=O)C(CC(N)=O)NC(=O)C1CCCN1C(=O)CNC(=O)C(Cc1ccc(O)c(O)c1)NC(=O)C(Cc1ccc(O)c(O)c1)NC(=O)C(CC(=O)[O-])NC(=O)C(C)N</smiles><smiles></smiles><smiles></smiles>

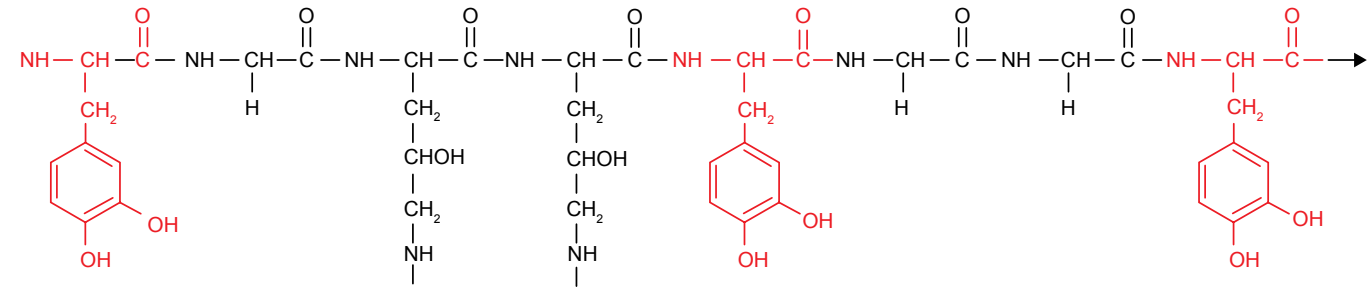
$\mathrm{C}=\mathrm{NH}_{2}^{+} \quad \mathrm{C}=\mathrm{NH}_{2}^{+}$

$\mathrm{NH}_{2} \quad \mathrm{NH}_{2}$

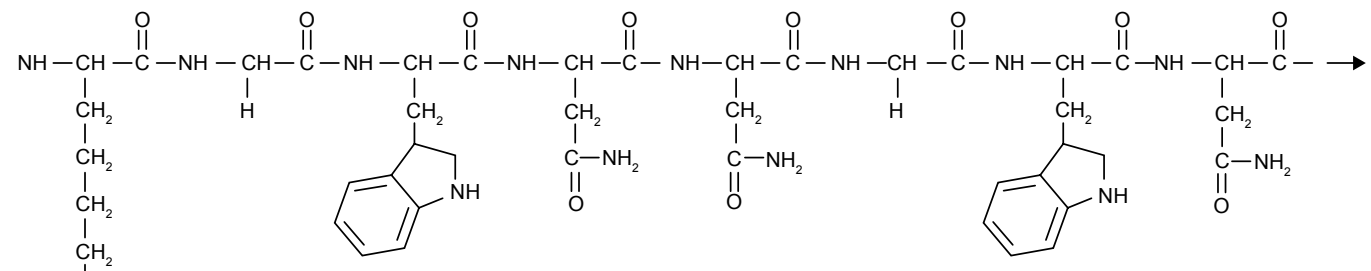
$\mathrm{NH}_{3}{ }^{+}$

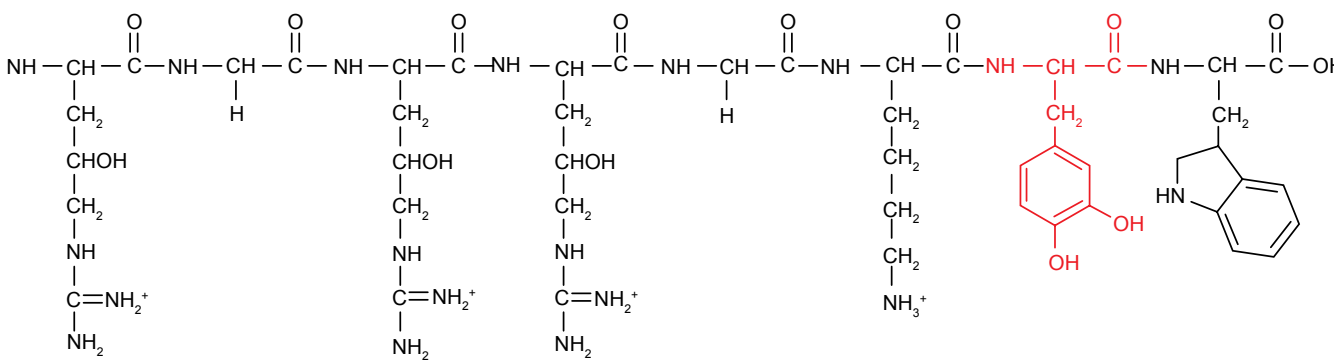

Figure 6 (A) Structure of byssi in mussels. (B) Chemical structure of a Dopa-rich mussel foot protein (mfp).

Note: Reproduced with permission of Annual Review of Materials Research, Vol 4I, @ by Annual Reviews, http://www.annualreviews.org, from Lee BP, Messersmith PB, Israelachvili JN, Waite JH. Mussel-inspired adhesives and coatings. Annual review of materials research. 201 I;41:99.40 

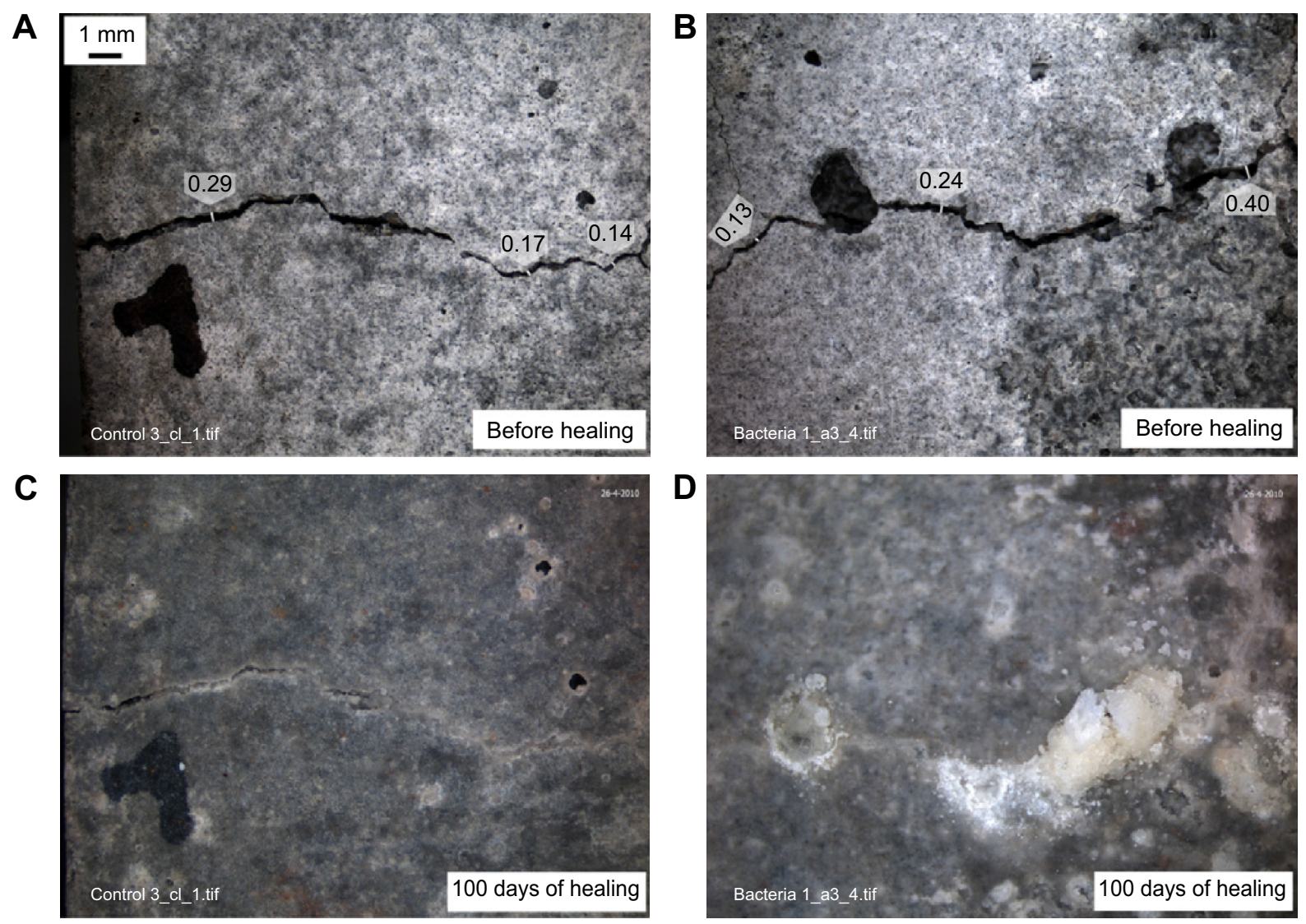

Figure $\mathbf{7}$ Images of the crack-healing process in control mortar specimens before (A and $\mathbf{B})$ and after 100 days of healing (C and D).

Note: Reprinted from Wiktor V, Jonkers HM. Quantification of crack-healing in novel bacteria-based self-healing concrete. Cem. Concr. Compos. 201 I;33(7):763-770, with permission from Elsevier. ${ }^{46}$

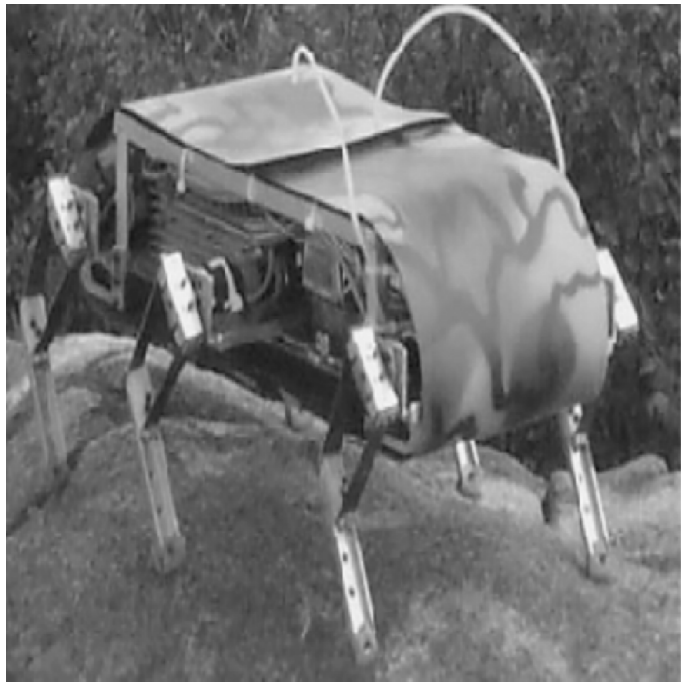

Figure 8 Image of RHex.

Notes: Reproduced with permission from Altendorfer R, Moore N, Komsuoglu $\mathrm{H}$, et al. RHex: a biologically inspired hexapod runner. Autonomous Robots. 200I;II(3):207-213, with kind permission from Springer Science and Business Media. ${ }^{52}$

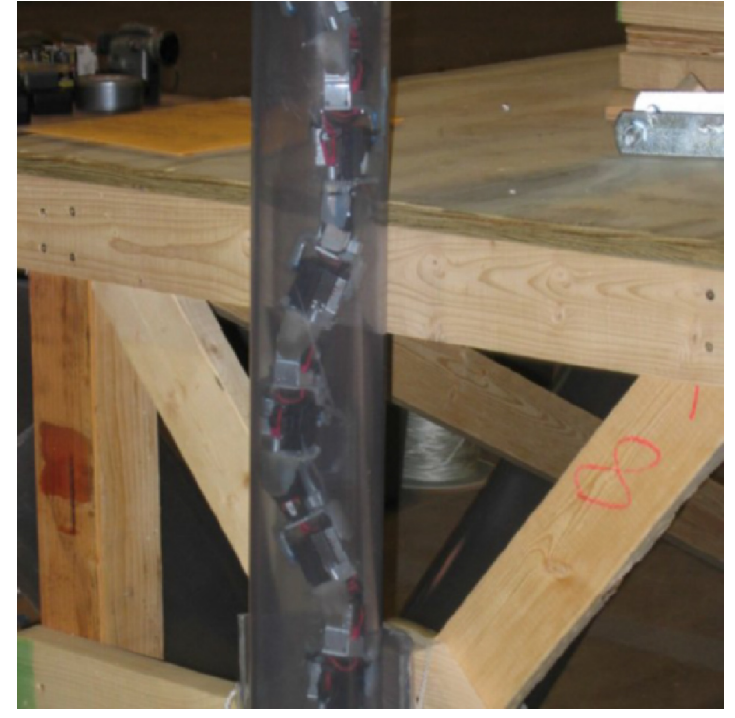

Figure 9 Image of the snake robots.

Note: ( 2007 IEEE. Reproduced with permission, from Wright C, Johnson A, Peck A, et al. Design of a modular snake robot. Paper presented at: Intelligent Robots and Systems, 2007. IROS 2007. IEEE/RSJ International Conference on 2007. ${ }^{53}$ 
$\$ 1$ trillion in market size. In the US alone, it is expected to have a $\$ 35$ billion market with over 1.6 million new job opportunities. . $^{2,53,54}$

\section{Present and future of biomimetics}

In promoting the coexistence of nature and humans, the economic, environmental, and social aspects of biomimicry are increasingly in demand and greater is the scope of application. Developed countries are actively investing in research to build the foundations for future innovation and development in biomimicry. ${ }^{2}$

After Janine M Benyus established the consulting companies Biomimicry Institute and the Biomimicry Guild, she created the website Asknature.org to use as a platform for advancing biomimetic technology in the USA. Furthermore, the New York State Energy Research and Development Authority (NYSERDA) is enforcing the use of biomimicry to solve various problems in energy.

Twenty-eight research centers studying biomimetics have collaborated to establish BIOKON in Germany. Sponsored by the Federal Ministry of Education and Research in Germany, 35 projects involving biomimetic products and technology are being conducted. In the UK, The Biomimetics Network for Industrial Sustainability (BIONIS), a network that connects businesses with universities is being operated. The Ministry of Education, Culture, Sports, Science and Technology is carrying out the Century Center of Excellence, a graduate program focusing on biomimetic monozukuri (biomimetic manufacturing) and novel uses of biotic resources in the field of agriculture in Japan.

The majority of past biomimetic materials have been developed in Europe, and the functional mimicries mostly originated from nanoscale or microscale parts of insects and plants. In recent years, due to the advancement of nanotechnology, a new wave of biomimetics is being extended to the imitation of animals. Europe is at the center of development, and the USA and Japan are actively participating in research. Forefront of biomimetics research is being advanced by nanotechnology and is vigorously developed through the use of scanning electron microscopy -like electron microscopies that enable us to observe and analyze the structure, function, and physical properties of natural organisms. With these tools of nanotechnology, biomimetic engineers can investigate at the scale of single cells, especially for cell organelles and interactions between cells. The biomimetic analysis of communities of cell organelles and their structures would give us insights on how to develop nanoscale constructs that may behave or function as the cellular constructs perform. ${ }^{55}$
Dr Stephen Mann at the University of Bristol suggested that biology and nanoscale phenomena share similar behaviors and functions. ${ }^{55}$ For example, phospholipids are one of the major cell constitutes and extracted molecules of them spontaneously self-assemble in water to produce vesicles or liposomes. The self-assembly rates of solubilized phospholipids are dependent on the molecular size and shape. The biomimetic study of the physicochemical property in phospholipids has helped to engineer self-assembling nanoparticles and nanostructures for drug deliveries, the protocell mimicking the cellular organelles and structures. The protocell has compartmentalized microarchitectures decorated with the assembly of protein-polymer nanostructure conjugates used for encapsulation or selective permeation of biomolecules, protein synthesis, and enzymatic activities. ${ }^{56}$ As shown in these examples, beyond incorporating biomimetics design into nanotechnology, applications of biomimetics in biomedical engineering have potential to significantly impact and create abundant value for human society in the future.

\section{Biomimetics in biomedical engineering}

With designs originating from organisms, biomimetics has facilitated and improved human life through many convenient products. In the future, biomimetics will have a greater impact through the combination of medicine, science, and biomedical engineering to treat diseases, physical disabilities, and wounds. Regenerative medicine and tissue engineering are particularly promising fields. Principles and functions of biomimetics that can be applied in biomedical engineering are derived from many sources, including how a lizard regenerates its tail and a buckhorn regenerates its horns every year, the adhesive, plegmatical, and regenerative properties of a spider web, and leukocyte adhesion/migration in inflammation.

An example would be a biocompatible medical bandage that can be made compatible with human tissue and integrated with a ubiquitous health care (U-health) system to get real time reports on the granular status of recovery or disease. A biocompatible, short-lived medical bandage or tape can be used to detect signals, allowing us to monitor heart attacks or myocardial infarction that cannot be monitored or detected using current medical devices. Such a bandage would also be compatible with our skin and result in fewer side effects and less irritation despite better attachment. Such function is derived from the foot hair of the gecko, as mentioned previously. ${ }^{57}$

Next-generation biomimetics combines biology with other technology in solving problems. In particular, nanotechnology 
is becoming a key discipline that will be utilized to help understand the material and its structures along with accelerating development of secondary structure of proteins. Proteinfunctionalized nanoparticles, peptide-functionalized gold nanoparticles, and carbohydrate-functionalized nanoparticles are areas of nanotechnology that are finding biomimetic applications..$^{58}$ Furthermore, biomimetic approaches may open up promising new fields. Various hybrid composites inspired by the nature have been fabricated and used as a template that can regulate biological processes in tissue engineering. Structural biomaterials such as bones or nacres are hierarchically constructed and organized. In order to elucidate the structural complexity of these biomaterials, studies have demonstrated the development of morphological structures of inorganic-organic hybrid materials to mimic biological and structural formations like sponge spicule formation or the nacre (brick-and-mortar) structure of mollusks. ${ }^{59}$

Multifunctional fibrous scaffolds have been developed as native tissue architecture, which have high potential for bone regeneration. One group recently tested nanofibers as a scaffold made of poly D,L-lactide-co-trimethylene carbonate (PLMC). The biomimicking attributes of poly D,L-lactideco-trimethylene carbonate nanofibers showed enhanced efficacies and efficiencies as scaffold materials for tissue repair and regeneration. ${ }^{60}$

The integration of biomimetics in biomedical engineering is advancing technology in many ways. Painless syringe needles developed by Kansai University (Osaka, Japan) is one example of biomimetics meeting bioengineering to develop a new material to improve medical operations. This group modeled the structure of mosquito mouthparts that are able to extract blood from the host animal with the least amount of nerve irritation. Such needles are used to help diabetics or during surgery to help patients overcome fear of needles. They use a biodegradable polymer, polylactic acid, which makes the needles safer and more practical than traditional microsilicon needles. Such needles can be inserted at particular angles with certain sensitivity to result in painless insertion. Painless needles are a great example of significant contribution to advancement of biomimetics and biomedical engineering. ${ }^{61,62}$

Due to the heterogeneous nature of the cellular microenvironments, biomimetic analytical platforms conveying complex environments in vivo models have been studied to probe the characteristics of cells and their microenvironments. ${ }^{63}$ By engineering the microenvironments (ie, microwells), researchers mimicked the cell-to-cell interactions in lymph nodes or other tissues where two types of cells dynamically communicate upon immunological cues. As the biomimetic microenvironments become more elaborated and sophisticated, researchers preparing biomimetic cellular environments will be enlightened and find solutions to the enigmatic relationships between cells and their adjacent microenvironment.

\section{Conclusion}

Biomimetics or biomimicry have been used and advanced even without formal research in many areas. Accumulating creative ideas as a foundation, mankind has accelerated the speed of development and evolution of civilization. However, such rapid industrialization has resulted in environmental pollution and a shortage of natural resources that is threatening the survival and future of humanity. As a result, it has become critical and urgent to find alternative methods to engineer materials, products, and services. Biomimetics is potentially the best method to help us cope with future development of civilization, environmental pollution, and resource shortage threats.

We believe that biomimicry has the best potential to be harmonious with nature while resulting in better outcomes than any artificial means of development. Animals, plants, and insects have utilized such technology to establish their ecosystem with no adverse effects to nature, and such behavior and way of life is what we humans may need in the current era. Even meager creatures show that they have evolved in their DNA and surface structures over lengthy periods of time and contain a compressed set of technology that we may learn from.

As with many great ideas, biomimetics started from simple imitation of natural organisms. Over time, it has evolved through integration and combination with modern science and engineering to help us discover new materials, ways of combining nano/microstructures, applications, and alternative ways of production. Biomimetics has developed from mere imitation to a stage where we are using the structures and functions of nature to create. Soon, we will be able to take ourselves to the next stage, where we can apply the newly discovered principles of biomimetics to help us create an economy that better follows natural evolution and development. By building technology in such a manner, we hope to create a more stable and productive future where products are more biodegradable and more compatible with nature, rather than being destructive.

Our creativity for new materials and innovation is limited by how much we are able to employ the great idea bank of nature. Every organism on Earth has evolved through adaptation and survival of the fittest. The creatures have lost what 
made them weak and kept those technologies that kept them strong. As human beings, we have the responsibility to be stewards of this idea bank to increase the quality of living while overcoming the degenerative forces that may destroy the environment and the human condition. Advancements in biomimetics hold the key to more cooperative evolution and technological development.

\section{Acknowledgments}

This work was supported by the research fund of Hanyang University (HY-2014-2082).

\section{Disclosure}

The authors report no conflicts of interest in this work.

\section{References}

1. Benyus JM. Biomimicry. HarperCollins e-books; 2009.

2. Shimomura M. The new trends in next generation biomimetics material technology: learning from biodiversity. Sci Technol Trends $Q R e v$. 2010;37:53-75.

3. Hargroves K, Smith M. Innovation inspired by nature: biomimicry. ECOS. 2006;2006(129):27-29.

4. Vincent JF, Bogatyreva OA, Bogatyrev NR, Bowyer A, Pahl A-K. Biomimetics: its practice and theory. $J$ R Soc Interface. 2006;3(9): 471-482.

5. Pemsel H. A History of War at Sea: An Atlas and Chronology of Conflict at Sea from Earliest Times to the Present. Naval Institute Press; 1977.

6. Freedman R. The Wright Brothers: How They Invented the Airplane. New York: Holiday House; 1991.

7. Jakab PL. Visions of a Flying Machine: The Wright Brothers and the Process of Invention. Smithsonian Institution Press; 1990.

8. Schmitt $\mathrm{OH}$. Some interesting and useful biomimetic transforms. Paper presented at: Proceeding, Third International Biophysics Congress; 1969; Boston, MA.

9. Rinaldi A. Naturally better. Science and technology are looking to nature's successful designs for inspiration. EMBO Rep. 2007;8(11): 995.

10. Pianka ER, Sweet SS. Integrative biology of sticky feet in geckos. Bioessays. 2005;27(6):647-652.

11. Goel AK, McAdams DA, Stone RB, editors. The AskNature Database: Enabling Solutions in Biomimetic Design. Biologically Inspired Design. Springer; 2013;20.

12. Lee DW, Graham R. Leaf optical properties of rainforest sun and extreme shade plants. American Journal of Botany. 1986;73:1100-1108.

13. Gabriel CT, Haskell J, Sethi S. Sacrificial multilayer anti-reflective coating for mos gate formation. Google Patents; 2001.

14. Velcro S. Improvements in or relating to a method and a device for producing a velvet type fabric. Swiss patent. 1955 (721338).

15. Stephens T. How a Swiss Invention Hooked the World. swissinfo; 2007. Available from: ch. http://www.swissinfo.ch/eng/search/Result.html

16. McSweeney TJ, Raha S, Staff C. Better to Light One Candle: The Christophers' Three Minutes a Day Millennial Edition. Continuum International Publishing Group, Limited; 1999.

17. Spiering JR. Roll-up Velcro tool carrier. Google Patents; 1987.

18. Roberts RM. Serendipity: Accidental Discoveries in Science. Wiley-VCH; 1989:288.

19. Ogilvie MA. Wild Geese. A\&C Black; 2010.

20. Alerstam T, Gudmundsson G, Jönsson P, Karlsson J, Lindström Å. Orientation, migration routes and flight behaviour of knots, turnstones and Brant Geese departing from Iceland in spring. Arctic. 1990;43:201-214.
21. Michelson RC, Naqvi MA. Beyond biologically \$ inspired insect flight. von Karman Institute for Fluid Dynamics RTO/AVT Lecture Series on Low Reynolds Number Aerodynamics on Aircraft Including Applications in Emerging UAV Technology. 2003:1-19.

22. Irwin DA, Pavcnik N. Airbus versus Boeing revisited: international competition in the aircraft market. $J$ Int Econ. 2004;64(2):223-245.

23. Wei H. Bionic design in car design. Mech Manag Dev. 2012;1:056.

24. Miller J. Biomimicry in engineering education. Proceedings of the Canadian Engineering Education Association. 2010.

25. O'Rourke JM, Seepersad CC. Examining Efficiency in Bioinspired Design. ASME; 2013. Paper No DETC2013-13147.

26. Neurohr R, Dragomirescu C. Bionics in engineering-defining new goals in engineering education at "politehnica" university of bucharest. Paper presented at: International Conference on Engineering Education-ICEE 2007.

27. Zari MP. Biomimetic Approaches to Architectural Design for Increased Sustainability. Auckland, New Zealand: 2007.

28. Bannasch R. Bionics. Technology Guide: Springer; 2009:178-183.

29. Wai R-J, Lee J-D, Chuang K-L. Real-time PID control strategy for maglev transportation system via particle swarm optimization. IEEE Trans Industr Electron. 2011;58(2):629-646.

30. Hood CP. Shinkansen: From Bullet Train to Symbol of Modern Japan. Routledge; 2006.

31. Sullivan T, Regan F. The characterization, replication and testing of dermal denticles of Scyliorhinus canicula for physical mechanisms of biofouling prevention. Bioinspir Biomim. 2011;6(4):046001.

32. Noirot C, Darlington JP. Termite Nests: Architecture, Regulation and Defence. Termites: Evolution, Sociality, Symbioses, Ecology. Springer; 2000:121-139.

33. Bonabeau E, Theraulaz G, Deneubourg J, et al. A model for the emergence of pillars, walls and royal chambers in termite nests. Philos Trans $R$ Soc Lond B Biol Sci. 1998;353(1375):1561-1576.

34. Emerson AE. Termite nests - a study of the phylogeny of behavior. Ecol Monogr. 1938;8:247-284.

35. Turner JS, Soar RC. Beyond biomimicry: what termites can tell us about realizing the living building. Paper presented at: Proc. 1st Int. Conf. Industrialized, Intelligent Construction 2008.

36. French JR, Ahmed BM. The challenge of biomimetic design for carbonneutral buildings using termite engineering. Insect Sci. 2010;17(2): 154-162.

37. Gunnell K, Du Plessis C, Gibberd J. Green Building in South Africa: Emerging Trends. Department of Environmental Affairs and Tourism (DEAT); 2009.

38. Arnold W. Singapore Offers an Architectural Symbol for the Arts. The New York Times; 2002:3.

39. Lee BP, Messersmith PB, Israelachvili JN, Waite JH. Mussel-inspired adhesives and coatings. Annu Rev Mater Res. 2011;41:99.

40. Deming TJ. Mussel byssus and biomolecular materials. Curr Opin Chem Biol. 1999;3(1):100-105.

41. Wilke P, Helfricht N, Mark A, Papastavrou G, Faivre D, Börner HG. A direct biocombinatorial strategy toward next generation, musselglue inspired saltwater adhesives. J Am Chem Soc. 2014;136(36): 12667-12674

42. Hong S, You I, Song IT, Lee H. Material-independent surface modification inspired by mussel-adhesion. Polym Sci Technol. 2012; 23(4):396-406

43. HoonáKim B, YoungáKim J, OukáKim S. Directed self-assembly of block copolymers for universal nanopatterning. Soft Matter. 2013; 9(10):2780-2786

44. Jonkers HM. Self Healing Concrete: A Biological Approach. SelfHealing Materials. Springer; 2007:195-204.

45. Wiktor V, Jonkers HM. Quantification of crack-healing in novel bacteria-based self-healing concrete. Cement Concr Compos. 2011; 33(7):763-770

46. Sobolev K, Gutiérrez MF. How nanotechnology can change the concrete world. Am Ceram Soc Bull. 2005;84(10):14. 
47. Hager MD, Greil P, Leyens C, van der Zwaag S, Schubert US. Selfhealing materials. Adv Mater Deerfield. 2010;22(47):5424-5430.

48. Seref-Ferlengez Z, Basta-Pljakic J, Kennedy OD, Philemon CJ, Schaffler MB. Structural and mechanical repair of diffuse damage in cortical bone in vivo. J Bone Miner Res. 2014;29(12):2537-2544.

49. Witte H, Hoffmann H, Hackert R, Schilling C, Fischer MS, Preuschoft H. Biomimetic robotics should be based on functional morphology. $J$ Anat. 2004;204(5):331-342.

50. Boxerbaum AS, Shaw KM, Chiel HJ, Quinn RD. Continuous wave peristaltic motion in a robot. Int J Robot Res. 2012;31(3):302-318.

51. Altendorfer R, Moore N, Komsuoglu H, et al. RHex: a biologically inspired hexapod runner. Auton Robots. 2001;11(3):207-213.

52. Wright C, Johnson A, Peck A, et al. Design of a modular snake robot. Paper presented at: IEEE/RSJ International Conference on Intelligent Robots and Systems, 2007. IROS 2007. 2007.

53. Absalom A, Absalom G, Hartmann D. A collaborative classificationbased search engine for prior art and solution search: Durham Zoo. Paper presented at: IEEE Sixth International Conference on Semantic Computing (ICSC), 2012. 2012.

54. Shimomura M. Engineering Biomimetics: Integration of Biology and Nanotechnology, Design for Innovative Value Towards a Sustainable Society. 2012:905-907.

55. Mann S. Life as a nanoscale phenomenon. Angew Chem Int Ed. 2008; 47(29):5306-5320.
56. Li M, Huang X, Tang TD, Mann S. Synthetic cellularity based on nonlipid micro-compartments and protocell models. Curr Opin Chem Biol. 2014;22:1-11.

57. Mahan GD. Amorphous Solid. School \& Library Products; 2014.

58. Gong Y-K, Winnik FM. Strategies in biomimetic surface engineering of nanoparticles for biomedical applications. Nanoscale. 2012;4(2): 360-368.

59. Müller WE, Wang X, Kropf K, et al. Bioorganic/inorganic hybrid composition of sponge spicules: matrix of the giant spicules and of the comitalia of the deep sea hexactinellid. J Struct Biol. 2008; 161(2):188-203

60. Bao M, Lou X, Zhou Q, Dong W, Yuan H, Zhang Y. Electrospun biomimetic fibrous scaffold from shape memory polymer of PDLLAco-TMC for bone tissue engineering. ACS Appl Mater Interfaces. 2014; 6(4):2611-2621.

61. Kim Y-C, Park J-H, Prausnitz MR. Microneedles for drug and vaccine delivery. Adv Drug Deliv Rev. 2012;64(14):1547-1568.

62. Izumi H, Suzuki M, Aoyagi S, Kanzaki T. Realistic imitation of mosquito's proboscis: electrochemically etched sharp and jagged needles and their cooperative inserting motion. Sens Actuators A Phys. 2011;165(1):115-123.

63. Choi J, Hwang MP, Lee J-W, Lee KH. A glimpse into the interactions of cells in a microenvironment: the modulation of $\mathrm{T}$ cells by mesenchymal stem cells. Int J Nanomedicine. 2014;9(suppl 1):127.
International Journal of Nanomedicine

\section{Publish your work in this journal}

The International Journal of Nanomedicine is an international, peerreviewed journal focusing on the application of nanotechnology in diagnostics, therapeutics, and drug delivery systems throughou the biomedical field. This journal is indexed on PubMed Central, MedLine, CAS, SciSearch $®$, Current Contents $\AA /$ Clinical Medicine,

\section{Dovepress}

Journal Citation Reports/Science Edition, EMBase, Scopus and the Elsevier Bibliographic databases. The manuscript management system is completely online and includes a very quick and fair peer-review system, which is all easy to use. Visit http://www.dovepress.com/ testimonials.php to read real quotes from published authors. 